\title{
PERANCANGAN RUMAH SAKIT PARU-PARU KELAS A DI JAKARTA TIMUR: KONSEP ARSITEKTUR ORGANIK
}

\author{
Muhamad Adiallah Hafiiz ${ }^{1}$, Rita Laksmitasari Rahayu ${ }^{2}$, Karya Widyawati ${ }^{3}$ \\ ${ }^{1}$ Universitas Indraprasta PGRI, Program Studi Arsitektur \\ adiallahhafiz1@gmail.com \\ ${ }^{2}$ Universitas Indraprasta PGRI, Program Studi Arsitektur \\ ritalaxmi@gmail.com \\ ${ }^{3}$ Universitas Indraprasta PGRI, Program Studi Arsitektur \\ widyawatik@yahoo.co.id
}

\begin{abstract}
The tendency of increasing number of tuberculosis (TB) sufferers as a lung disease in Jakarta. Jakarta does not yet have a special lung hospital, so DKI Jakarta needs a special lung hospital. In addition to the large number of lung disease sufferers in Jakarta as the capital city of Indonesia and allowing a special lung hospital to be planned in Jakarta, the Special Lung Hospital is planned with a class A classification. This health facility is adequate both in capacity, quality and quantity. The research method uses descriptive qualitative and the design method uses the concept of organic architecture. The use of the concept of organic architecture can help improve patient healing. The application of the organic concept was chosen because it refers to harmony with the natural surroundings, creating a harmonious unity, which can last all the time with its dynamic form with nature. The results of this research and design make the organic concept have a good fit when applied to health service buildings, especially lung hospitals in terms of the concept applied in its design.
\end{abstract}

Key Words: Lung Hospital, Organic architecture, Nature's harmony.

\begin{abstract}
Abstrak : Kecenderungan meningkatnya angka penderita Tuberculosis (TBC) sebagai salah satu penyakit paru paru di Jakarta. Jakarta belum memiliki rumah sakit khusus paru paru, maka DKI Jakarta membutuhkan rumah sakit khusus paru-paru. Selain besarnya angka penderita penyakit paru paru di Jakarta sebagai Ibukota negara Indonesia dan memungkinkan rumah sakit khusus paru paru direncanakan di Jakarta maka Rumah Sakit Khusus Paru paru direncanakan dengan klasifikasi kelas A. Fasilitas kesehatan ini memadai baik dalam kapasitas, kualitas dan kuantitas. Metode penelitian menggunakan deskriptif kualitatif dan metode perancangan menggunakan konsep arsitektur organik. Penggunaan konsep arsitektur organik mampu membantu meningkatkan kesembuhan pasien. Penerapan konsep organik dipilih karena mengacu pada keselarasan dengan alam sekitarnya, menciptakan satu kesatuan yang harmonis, dapat bertahan sepanjang waktu dengan bentuknya yang dinamis dengan alam. Hasil penelitian dan perancangan ini tersebut menjadikan konsep organik memiliki kecocokan yang baik apabila diterapkan dalam bangunan pelayanan kesehatan terutama rumah sakit paru-paru dalam segi konsep yang diterapkan dalam desainnya.
\end{abstract}

Kata Kunci : Rumah Sakit Khusus Paru, Arsitektur organik, Keselarasan alam.

\section{PENDAHULUAN}

Paru-paru merupakan salah satu organ yang berperan penting dalam menjalankan sistem pernapasan. Saat udara mencapai paru-paru, akan terjadi pertukaran antara oksigen dari luar tubuh dengan karbon dioksida dari dalam darah. Jika paru-paru mengalami gangguan, maka proses ini pun akan ikut terganggu dan mempengaruhi organ tubuh yang lain. Hal ini diperparah dengan adanya penyakit baru berupa virus Covid-19 yang menyerang sistem pernafasan sejak akhir tahun 2019.

Jumlah penduduk Jakarta sebanyak 10.151.403 orang pada tahun 2020 dan diprediksi pada tahun 2025 penduduk Jakarta menjadi 10.453.850 penduduk. Jumlah penduduk Jakarta yang kemungkinan pengidap penyakit paru pun banyak dan dari tahun ke tahun terus meningkat. Sementara penderita penyakit paru di Jakarta, dilayani oleh rumah sakit yang memiliki pelayanan penyakit paru paru seperti Rumah Sakit Umum Daerah (RSUD), Rumah Sakit Umum Pusat (RSUP), Direktorat Kesehatan, dan lainnya. Salah satu penyakit paru-paru yang diidap oleh penduduk Jakarta adalah tuberkulosis (TBC). Pada tahun 2015 warga DKI Jakarta penderita penyakit TBC hanya 23.133 orang. Pada perkembangannya, pada tahun 2018 jumlah tersebut meningkat 
menjadi 32.570 penderita atau kurang lebih sebesar 0,3\% dari total penduduk DKI Jakarta. Pada tahun 2030, Dinas Kesehatan Provinsi DKI Jakarta memberikan target warga Jakarta terbebas dari penyakit tuberkulosis (TBC) (statistic.jakarta.go.id,2019). Jakarta sebagai ibu kota Indonesia belum memiliki rumah sakit khusus paru-paru. Jakarta perlu memiliki sarana dan prasarana pelayanan kesehatan paru-paru. Kapasitas, kualitas, dan kuantitas sesuai syarat pelayanan kesehatan. Jakarta sangat penting dan strategis untuk memiliki Rumah Sakit Khusus Paru-paru ini, karena sifatnya yang mengharuskan sarana prasarana lengkap dan terbaik sebagai Ibukota Negara. Jakarta membutuhkan Rumah Sakit Khusus Paru-paru dengan kelas A.

Lokasi didirikannya Rumah Sakit ini berada di Kecamatan Cakung Jakarta Timur, Daerah Khusus Ibukota Jakarta. Pemilihan lokasi sesuai dengan keperuntukan lahan berdasarkan RTRW Jakarta Timur, yaitu sarana dan prasarana palayanan kesehatan. Konsep Rumah Sakit Khusus Paru-paru ini adalah organik yang mengacu pada metode pemberian material alami sebagai sarana bantu secara psikologis untuk penyembuhan pasien.

Rumah Sakit Khusus Paru-paru memberikan pelayanan utama pada satu bidang atau satu jenis penyakit tertentu yaitu penyakit yang berkaitan dengan paru paru (UU no 44/2009). Rumah Sakit Umum Kelas A mempunyai fasilitas dan kemampuan pelayanan medik spesialistik luas dan subspesialistik luas (PMK56/2014).

Bangunan gedung rumah sakit pada umumnya termasuk bangunan kesehatan publik yang memenuhi syarat keandalan bangunan. Sebagai bangunan vital harus memenuhi persyaratan keselamatan, kesehatan, kenyamanan, dan kemudahan (PerMenPUPR,26/2006). Dari keempat syarat keandalan bangunan tersebut, maka Rumah Sakit Khusus Paru paru memperhatikan keempat faktor keandalan bangunan.

Pada prinsip keselamatan, aspek patient safety adalah prinsip dasar dari perawatan kesehatan (WHO). Keselamatan pasien adalah ada tidak adanya kesalahan atau bebas dari cidera karena kecelakaan. Kesehatan merupakan keadaan fisik, mental, dan sosial kesejahteraan dan bukan hanya ketiadaan penyakit atau kelemahan. Kenyamanan adalah rasa yang timbul jika seseorang merasa diterima apa adanya, serta senang dengan situasi dan kondisi yang ada sehingga seseorang akan merasakan kenyamanan.
Rumah Sakit Khusus Paru paru kelas A ini menggunakan konsep organik. Konsep organik memiliki pemahaman keselarasan dengan alam sekitarnya dan menciptakan satu kesatuan yang harmonis. Selain itu konsep organik ini dapat bertahan sepanjang waktu dengan bentuknya yang dinamis dengan alam.

\section{METODOLOGI \\ Pengumpulan Data}

Pengumpulan data ini mulai bulan Januari 2019 sampai Januari 2020. Pengumpulan data menggunakan metode wawancara, observasi langsung, dan arsip. Tujuan pengumpulan data terbuka yaitu mendokumentasikan data untuk digunakan pada tahap analisa perancangan. Arah pengumpulan data fleksibel.

Pengumpulan data pada tahap pertama berupa data literatur yang terdiri dari sumbersumber handbook tentang bangunan rumah sakit, pengumpulan data menggunakan pengamatan lapangan berupa dokumentasi. Sedangkan teknik wawancara akan dilakukan pada bagian operasional rumah sakit terutama pada tahap perawatan dan pengembangan bangunan.

\section{Wilayah Penelitian}

Pemilihan obyek adalah rumah sakit khusus paru paru. Penelitian diawali dengan studi literatur dan preliminary observation atau pengamatan awal secara menyeluruh. Latar belakang pemilihan wilayah penelitian ini sebagai berikut: berada di daerah administrasi DKI Jakarta dan memiliki peruntukan sebagai sarana kesehatan.

\section{Teori}

Arsitektur organik merupakan hasil dari perasaan akan kehidupan, seperti integritas, kebebasan, persaudaraan, harmoni, keindahan, kegembiraan dan cinta.Terdapat empat landasan utama dalam konsep arsitektur organik pada bangunan rumah sakit paru-paru.yaitu:

\section{a. Building as nature}

Bangunan Arsitektur Organik bersifat alami. Rumah sakit paru-paru banyak menerapkan unsur vegetasi pada area sirkulasi koridor dan material yang bersifat alami pada desain interiornya.

\section{b. Form follows flow}

Menggunakan form follow flow (bentuk mengikuti energi). Bentuk bangunan dengan Arsitektur Organik mengikuti aliran energi dari alam.

\section{c. Of the people}


Desain dipengaruhi oleh hubungan dengan pemakai bangunan.

\section{d. Of the materials} material.

Bangunan berekspresi menggunakan

\section{HASIL DAN PEMBAHASAN Lokasi Tapak}

Rencana tata ruang Wilayah RTRW Kecamatan Cakung Jakarta timur berdasarkan Perda Provinsi DKI Jakarta, dimana yang berwarna coklat S.2 sub zona prasarana kesehatan.

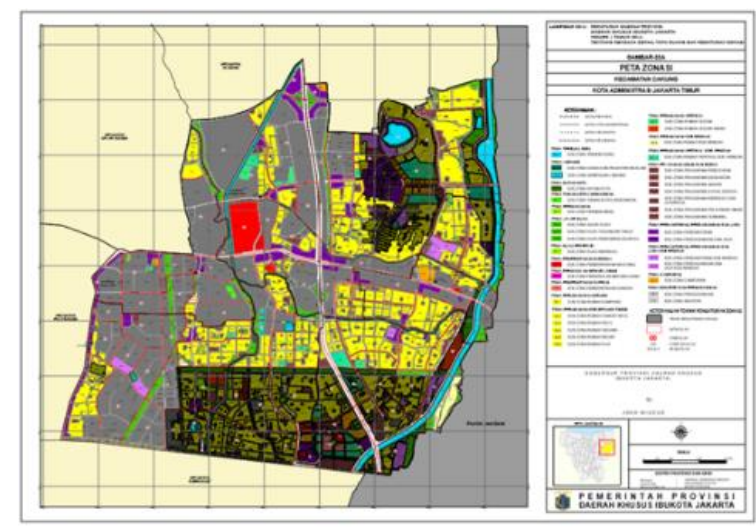

Gambar 1 Peta RTRW

Sumber : Perda DKI Jakarta, 2020

Kecamatan Cakung Jakarta Timur memiliki luas: 4.248,08 hektar dengan jumlah penduduk 66.444 jiwa dengan kepadatan 6.773 jiwa $/ \mathrm{km}^{2}$. untuk luas tapak yang akan dibangun rumah sakit paru-paru ini berukuran 9,700 m2 .
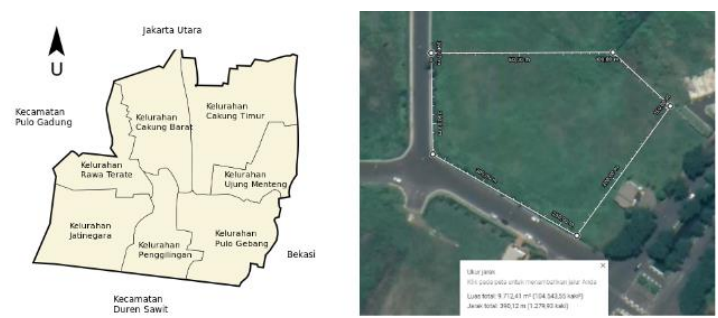

Gambar 2 Lokasi dan Ukuran Site Sumber : Google.com, 2020

\section{Kriteria Pemilihan Tapak}

Pemilihan lokasi rumah sakit khusus paruparu harus berdasarkan hasil analisa, walaupun peruntukan lahan yang dibangun untuk pelayanan kesehatan akan tetapi dari segi lingkungan sekitar belum tentu ada kecocokan terutama untuk penyembuhan penyakit yang berasal dari paruparu, oleh sebab itu dibuatlah beberapa data tersebarnya rumah sakit paru-paru yang ada di Indonesia beserta data mengenai lingkungannya sebagai berikut;

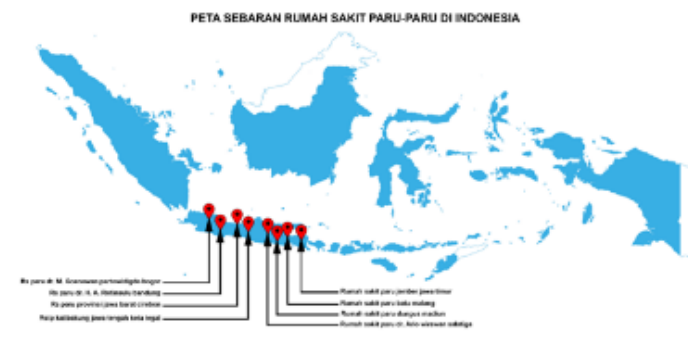

Gambar 3 Peta Sebaran Rumah Sakit Paru

Sumber : google.com, analisa pribadi, 2020

Dari data analisa yang di kumpulkan mengenai peta sebaran rumah sakit paru-paru yang ada di Indonesia yang dikaitkan dengan dataran masing-masing daerah rumah sakit tersebut disimpulkan bahwa mendirikan rumah sakit paruparu di Kecamatan Cakung Jakarta Timur bisa dilakukan.

Tabel 1 Data Rumah Sakit Paru

\begin{tabular}{|c|c|c|c|}
\hline DAERAH & IINGGI DPL DAERAH & SUHU RATA-RATA & JENISDATARAN \\
\hline $\begin{array}{l}\text { Bogox } \\
\text { Bandang }\end{array}$ & 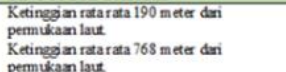 & $\begin{array}{l}\text { Sulu rataratata } 26^{\circ} \mathrm{C} \\
\text { Sulu ratarate } 23,5^{\circ} \mathrm{C}\end{array}$ & $\begin{array}{l}\text { Dzaran partí } \\
\text { Dstaran tingy }\end{array}$ \\
\hline $\begin{array}{l}\text { Cirebon } \\
\text { Tegal }\end{array}$ & 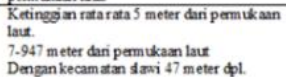 & $\begin{array}{l}\text { Sulu ratarata } 22,3^{\circ} \mathrm{C} \\
\text { mak } 33^{\circ} \mathrm{C} \\
\text { Suhu ratarata } 35^{\circ} \mathrm{C}\end{array}$ & $\begin{array}{l}\text { Datarm portai } \\
\text { Datarn partai }\end{array}$ \\
\hline Jember & $\begin{array}{l}\text { Ketingeg in ratarata } 100-500 \text { m eter dari } \\
\text { pemulean laut }\end{array}$ & $\begin{array}{l}\text { Sulu ratarata } 238 \mathrm{mdk} \\
31^{\circ} \mathrm{c}\end{array}$ & \begin{tabular}{|l|l} 
Dataran sedng \\
\end{tabular} \\
\hline Malng & $\begin{array}{l}\text { Ketingegn ratarata 440-667 mete dani } \\
\text { permukan laut }\end{array}$ & $\begin{array}{l}\text { Sulue ritarata } 22,7^{\circ} \mathrm{C} \\
\text { mak } 25,1^{\circ} \mathrm{C} .\end{array}$ & Datarn sedng \\
\hline Madiun & 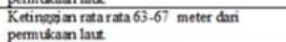 & $\begin{array}{l}\text { Sulum ratarata } 20^{\circ} \mathrm{cm} \text { ak } \\
35^{\circ} \mathrm{C}\end{array}$ & Dataran partai \\
\hline Salatiga & $\begin{array}{l}\text { Ketingegin ratarata } 525-675 \text { meter dari } \\
\text { petmulvan laut }\end{array}$ & Sulu ratarata $26.25 \mathrm{c}$ & Datarn sedng \\
\hline
\end{tabular}

Sumber : google.com, analisa pribadi, 2020

Salah satu syarat membangun Rumah Sakit khusus Paru paru adalah bangunan gedung berada di daerah dataran pantai 0-200 meter dari permukaan laut. Contoh rumah sakit khusus paru paru yang memiliki karakteristik di dataran rendah adalah rumah sakit paru provinsi jawa barat Cirebon, RSTP Kalibakung Jawa Tengah Kota Tegal, dan Rumah Sakit Paru Dungus Madiun.

\section{Potensi Lahan}

Lahan tapak masih tergolong alami dan dalam kondisi tidak ada bangunan di dalam tapak.. Kondisi eksisting seperti ini memudahkan rancangan kawasan rumah sakit. Sesuai dengan konsep arsitektur organic maka kondisi alam seperti ini juga perancang dapat optimal bereksporasi menggunakan konsep arsitektur organik. Perancang tetap memperhatikan alam dengan optimal mendisain menyatu dengan alam atau site dan tanpa merusak alam. 


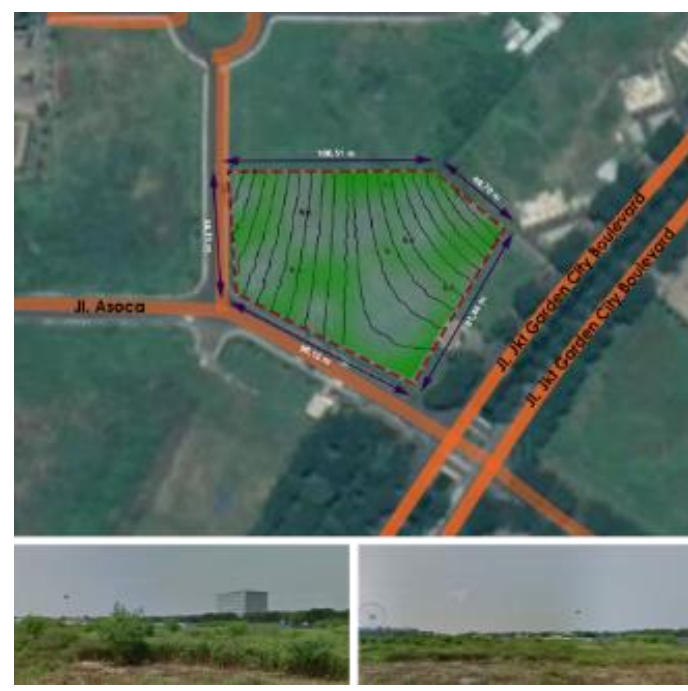

Gambar 4 Potensi Lahan

Sumber : analisa pribadi, 2020

\section{Analisa Iklim}

Matahari

Penerapan shading tumuhan merambat digunakan untuk menfiltrasi bagian dalam rumah sakit agar tidak masuk langsung kedalam bangunan.

Aspek ekologis bangunan organik akan dimunculkan pada sistem pencahayaan dan penghawaan yang dapat memaksimalkan pencahayaan dan penghawaan alami.

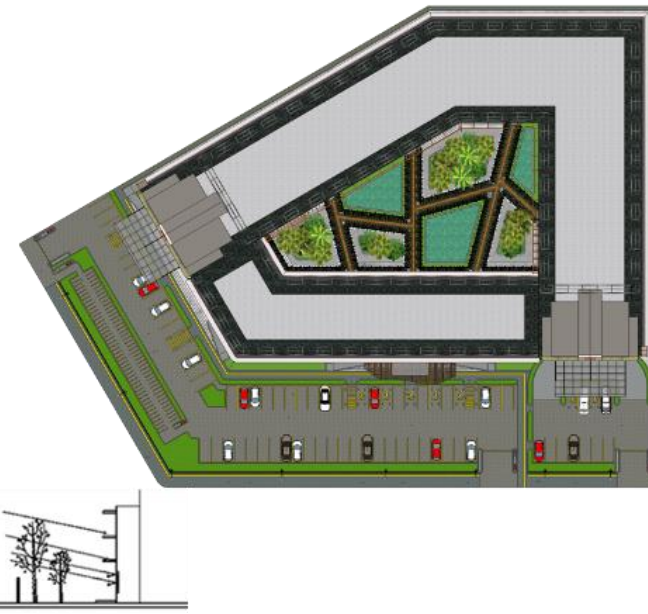

Gambar 5 Matahari

Sumber : analisa pribadi, 2020

\section{Angin}

Pengunaan dinding hijau digunakan segala untuk mencapai keselarasan antara desain bangunan, manusia, dan lingkungannya.

Warna bangunan ini yang cenderung memilih warna-warna alam yakni cokelat muda dan hijau pada vegetasinya, membuat bangunan ini sesuai dengan lingkungan alam yang ada.

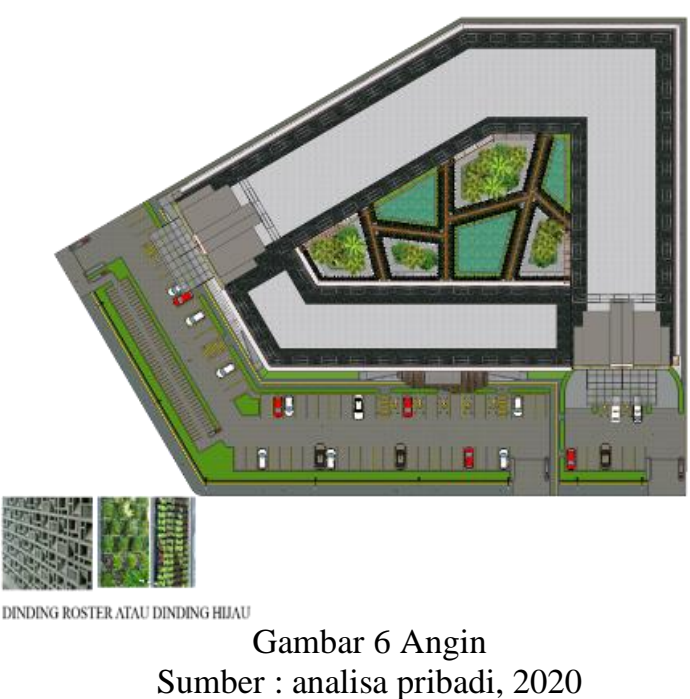

Hujan

Pembuatan kolam buatan akan menciptakan suasana yang segar.

Penerapan vegetasi dan kolam buatan mampu dipadukan agar menciptakan keterhubungan dengan alam.

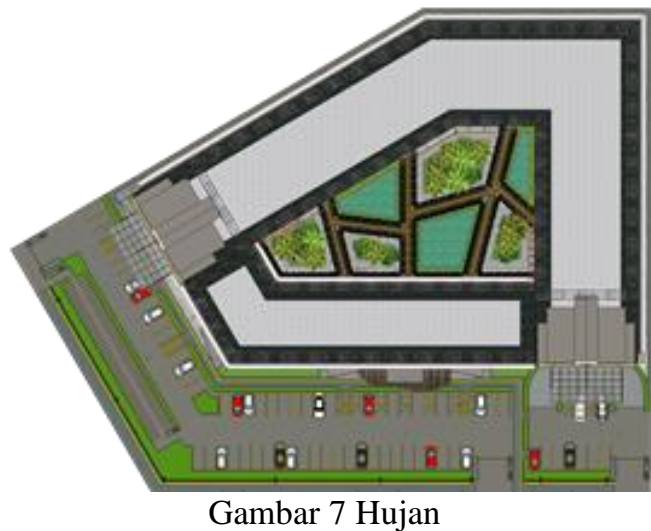

Sumber : analisa pribadi, 2020

\section{Tranformasi Bentuk}

Bentuk tranformasi dianalogikan dari paru-paru karena vegetasi dan pepohonan merupakan seuatu simbolis dari paru-paru dunia. Bentuk terlihat sederhana. 


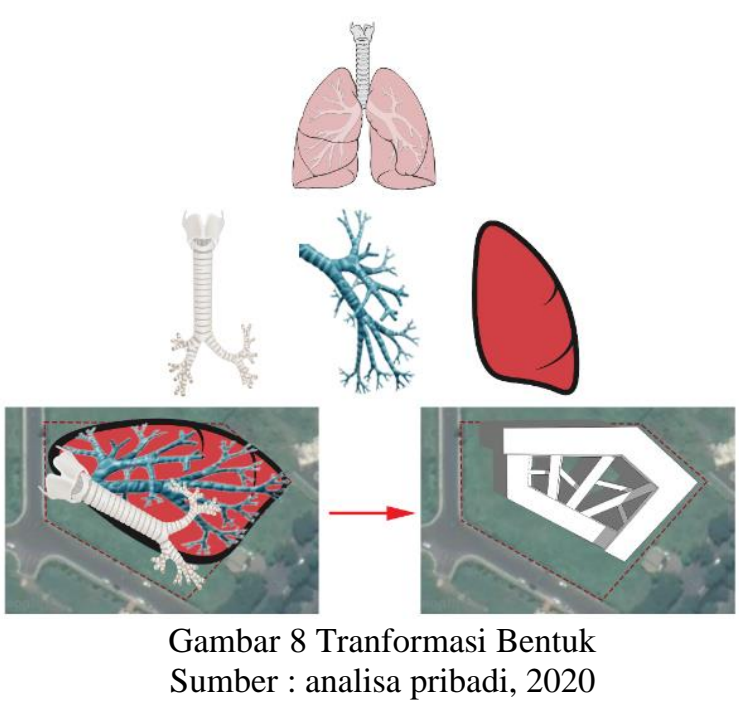

Bentuk dilihat sebagai keterangan yang menunjukan struktur internal dan skema eksternal suatu kesatuan arsitektur, dimana bentuk biasanya juga mencakup keadaan 3 dimensi (D.K. Ching, 2008).

Gestalt menegaskan bahwa otak akan memproses lingkaran visualnya dalam rangka untuk mengerti keadaan sekitarnya. Ketika melihat banyak bentuk, biasanya otak akan langsung fokus pada suatu bentuk yang lebih sederhana dan sering dilihat. Semakin sederhana bentuknya semakin gampang otak menerima dan mengerti.

\section{Penzoningan}

Persoalan peruangan menerapkan prinsip of the people. Kualitas ruang bangunan rumah sakit khusus paru-paru dipengaruhi oleh gaya internal yaitu aktivitas pengguna, kenyamanan pengguna, kebutuhan ruang, dan kriteria ruang dan zoning ruang. Pendekatan organik juga akan dimunculkan dengan menerapkan prinsip youthful and unexpected melalui penataan layout ruang, bentuk ruang yang beragam, juga fluktuasi pada level lantai yang beragam.
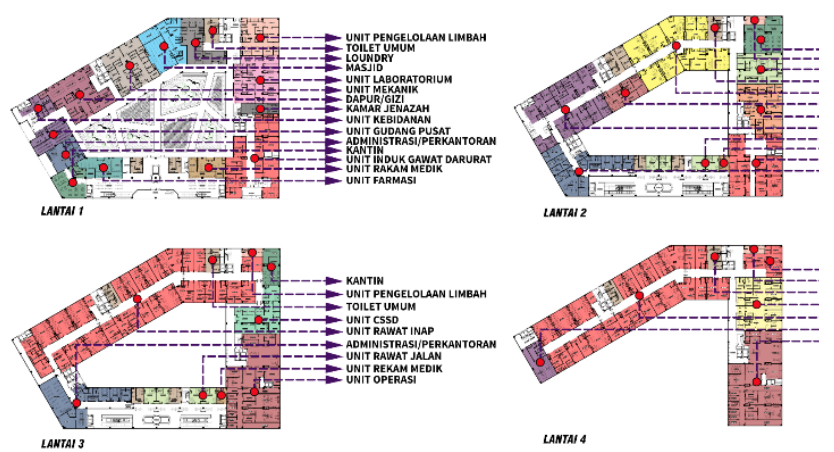

Gambar 9 Penzoningan

Sumber : analisa pribadi, 2020

\section{Hasil Desain \\ Eksterior}

Arsitektur organik lebih mengacu pada keselarasan dengan alam sekitarnya, menciptakan satu kesatuan yang harmonis dan hal tersebut diterapkan dengan mengunakan tanaman merambat, vegetasi dan kolam buatan pada area korridor.

Warna-warna alam yakni cokelat muda dan hijau pada vegetasinya, membuat bangunan ini sesuai dengan lingkungan alam yang ada.
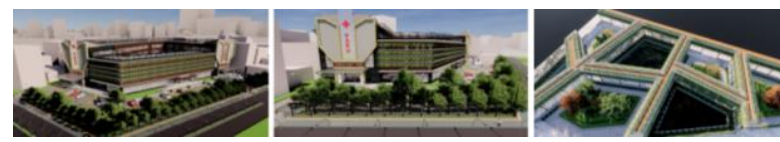

Gambar 10 Bird's eye, Bird's aye2, Korridor

Sumber : analisa pribadi, 2020

\section{Interior}

Desain yang harmonis antara lokasi bangunan, interior dan lingkungan menjadi bagian dari suatu komposis, dipersatukan dan saling berhubungan.

Dengna komposisi material yang alami dapat menciptakan bentuk-bentuk bebas dan material yang dapat berfungsi sebagai interior maupun eksterior.
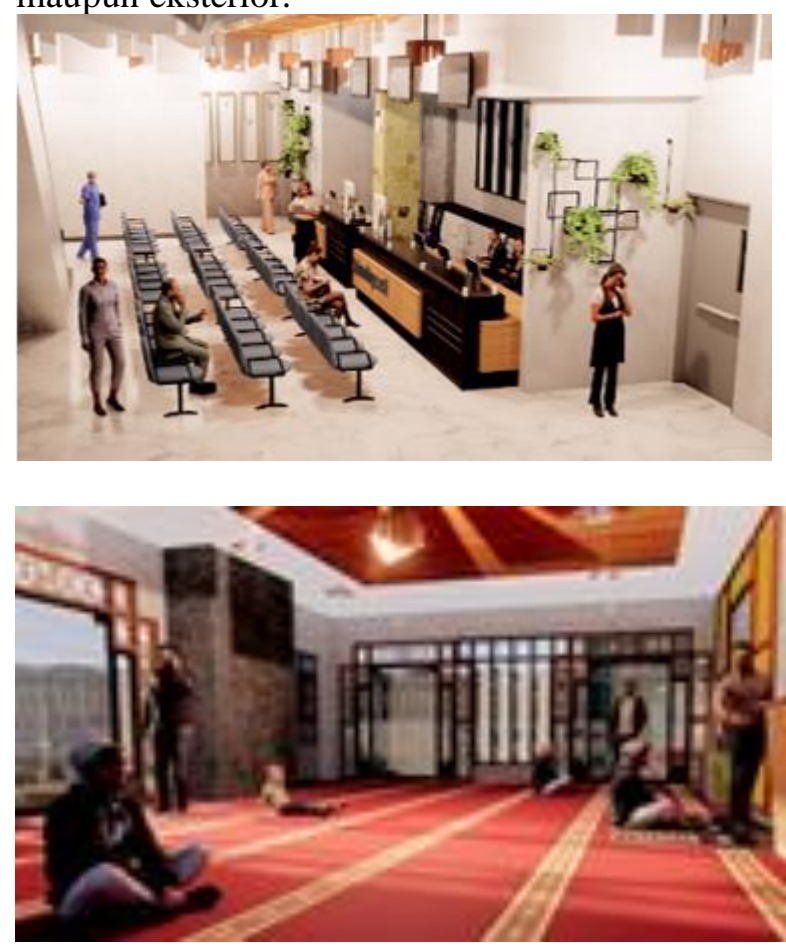


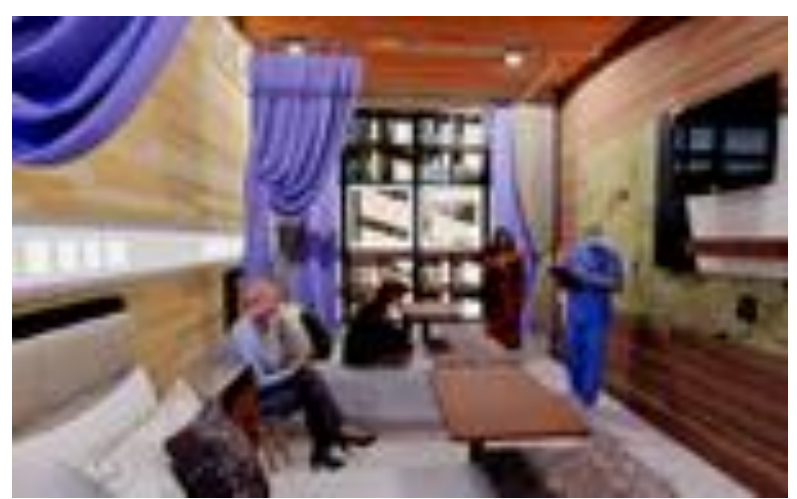

Gambar 11. Resepsions, Masjid, Ruang Rawat Inap Sumber : analisa pribadi, 2020

\section{Denah}
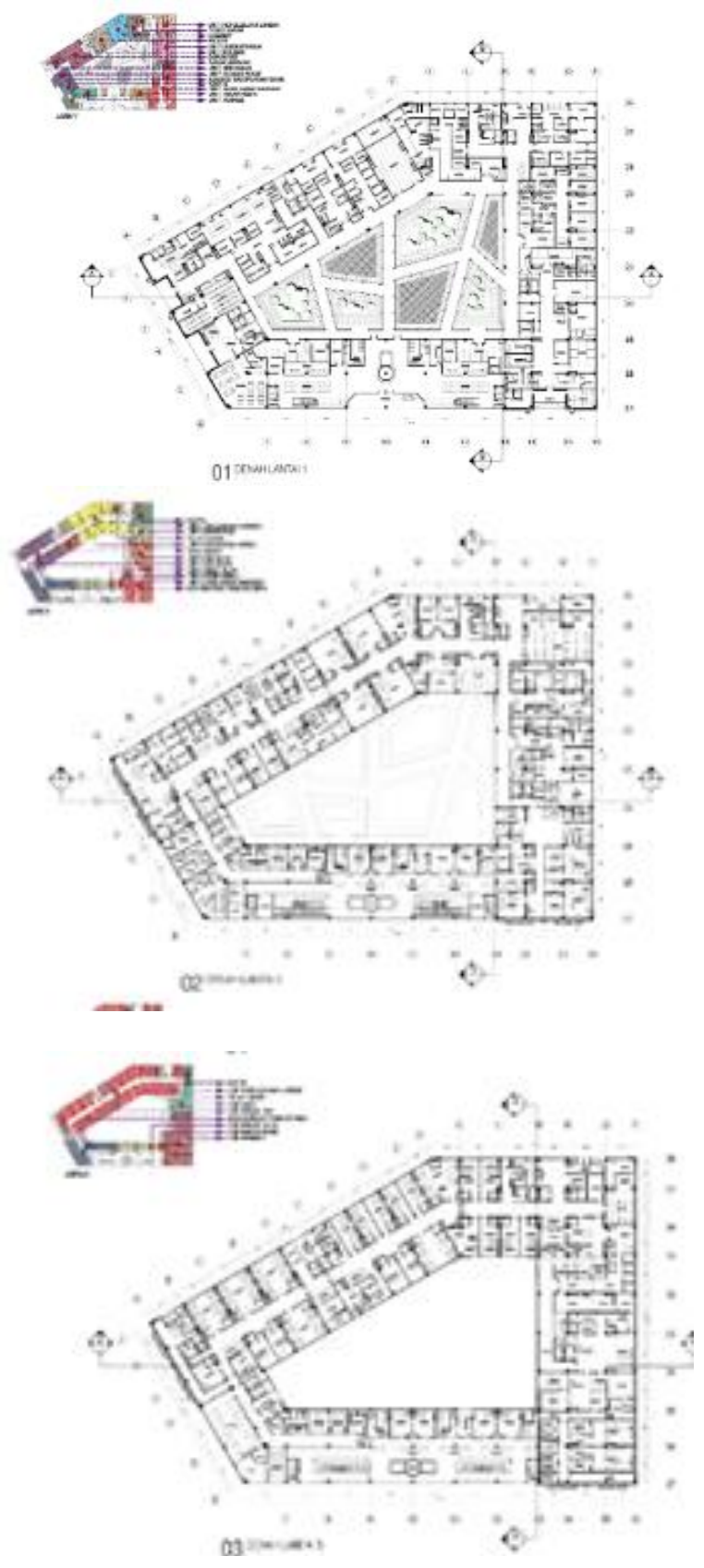

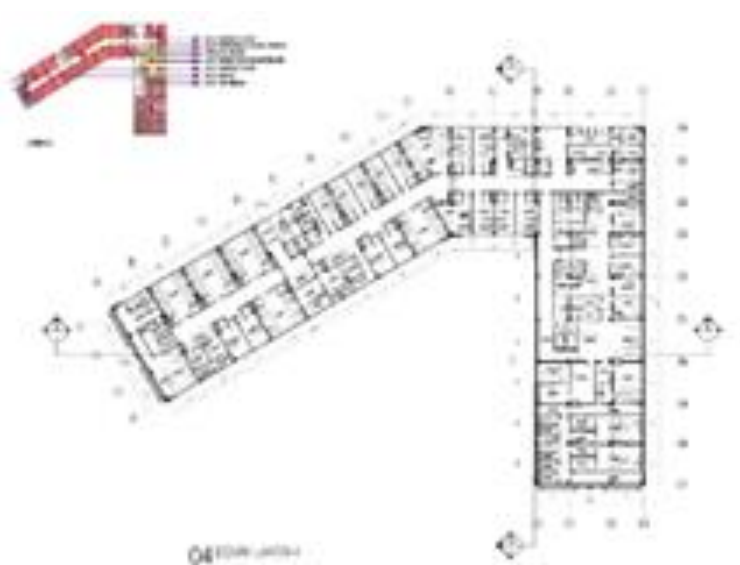

Gambar 12 Denah

Sumber : analisa pribadi, 2020

\section{Tampak}
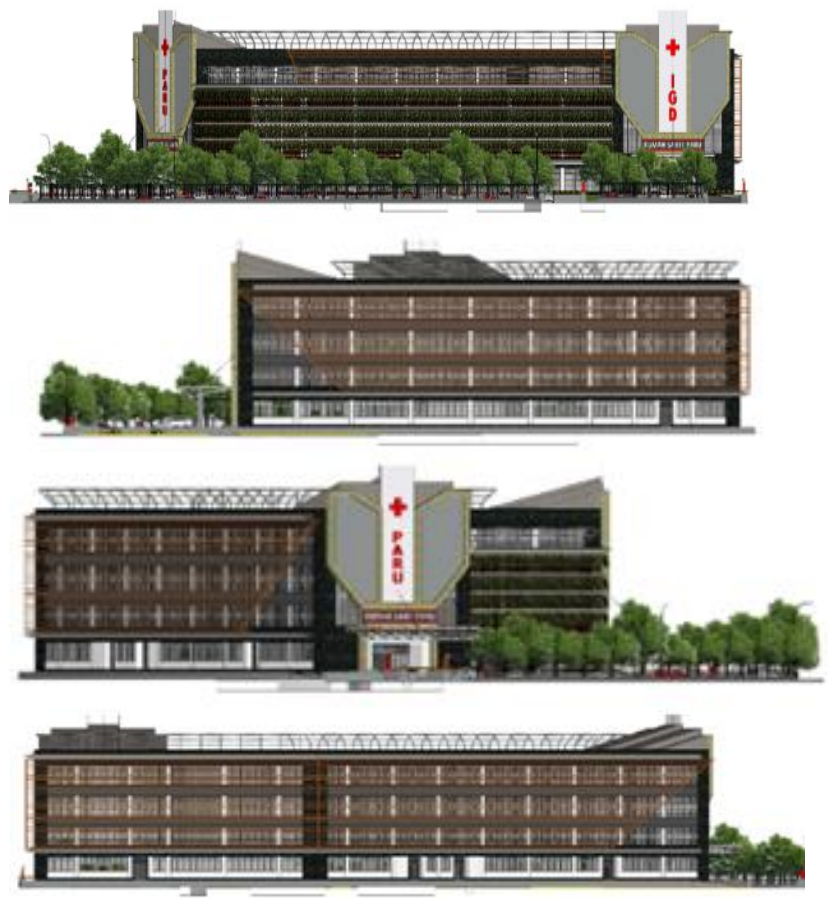

Gambar 13 Tampak

Sumber : analisa pribadi, 2020

\section{Potongan}

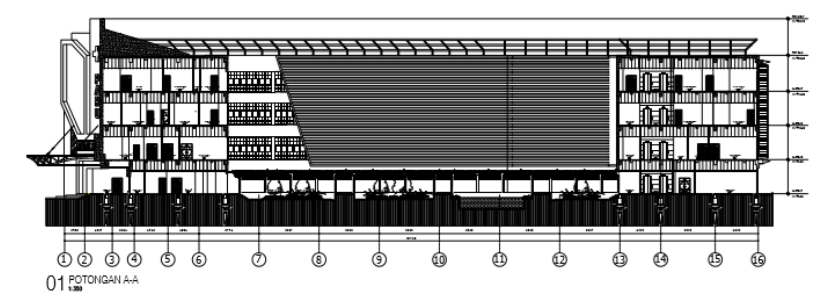

Gambar 14 Potongan

Sumber : analisa pribadi, 2020 
PENUTUP

Simpulan

Konsep organik merupakan konsep yang cenderum mengacu dengan alam, menyesuaikan alam sekitarnya secara dinamis, bukan melawan alam. Alam dalam hal ini dapat berupa angin, cahaya dan panas matahari, arus air, energi bumi dan lainnya. Konsep organik memiliki keterikatan hubungan dengan pemakai bangunan terutama dari material yang digunakan. Desain arsitektur organik dipengaruhi oleh aktifitas-aktifitas yang diwadahi pada bangunan, tujuan bangunan, kebutuhan pengguna, kenyamanan penggunanya dan keinginan penggunanya. Hal tersebut memiliki keungulan tersendiri pada bangunan pelayanan kesehatan seperti halnya rumah sakit karena menurut penelitian faktor warna dan alam, kedua aspek ini terbukti mampu membantu tingkat kesembuhan pasien.

\section{Saran}

Penelitian ini masih dapat dikembangkan lagi, seperti penerapan konsep arsitektur organik dengan menghitung energi yang digunakan pada bangunan rumah sakit khusus paru paru.

\section{DAFTAR PUSTAKA}

\section{Jurnal}

Ginting, S., \& Purwantiasning, A. W. (2016). Penerapan arsitektur organik pada perencanaan pusat penelitian dan pengembangan wisata alam mangrove di muara gembong, Bekasi. Jurnal Arsitektur PURWARUPA, 01(april), 6168.

Haq, A. A., \& Sudarma, E. (2017). Penerapan Healing Architecture dalam Desain Rumah Sakit. Jurnal Sains Dan Seni ITS, 6(1), $11-15$ https://doi.org/10.12962/j23373520.v6i1. 22579

Mozes, A., Dalawir, P., \& Tilaar, S. (n.d.). Sentra Industri Kai $N$ Koffo Di Mangani Tu (Arsitektur Organik). 46-55.

Rukayah, S. (2003). Penekanan Desain Arsitektur Organik Dan Green Architecture Pada Perancangan Pusat Rekreasi Dan Klub Pemancingan Di Rawapening, Kabupaten
Semarang. Jurnal Jurusan Arsitektur, 1, 45-54.

Setyoningrum, A., \& Anisa, A. (2019). Aplikasi

Konsep Arsitektur Organik Pada Bangunan Pendidikan. Langkau Betang: Jurnal Arsitektur, 6(1), 26. https://doi.org/10.26418/lantang.v6i1.329 $\underline{05}$

Sujanra, S. P. (2017). Penerapan Teori Arsitektur Organik Dalam Strategi Perancangan Pusat Pengembangan Industri Kreatif Di Bandung. Arsitektura, 15(2), 506. https://doi.org/10.20961/arst.v15i2.15316

Buku

Ernst Neufert (2002). Data Arsitek, Jilid 2, Jakarta: Erlangga, 2002.

Ching, Francis D.K. (2008). Arsitektur: Bentuk, Ruang dan Susunannya. Jakarta: Erlangga, 1994.

\section{Peraturan}

Pemerintah Indonesia. 2009. Undang-Undang No. 44 Tahun 2009 Tentang Rumah Sakit. Lembaran Negara RI Tahun 2009, No. 44. Sekretariat Negara. Jakarta.

Pemerintah Indonesia. 2016. Peraturan Menteri Kesehatan Republik Indonesia Nomor 24 tentang persyaratan teknis bangunan dan prasarana Rumah Sakit. Lembaran Negara RI Tahun 2016, No. 24. Sekretariat Negara. Jakarta.

Pemerintah Indonesia. 2020. Peraturan Menteri Kesehatan Republik Indonesia Nomor 3 tentang klasifikasi dan perizinan rumah sakit. Lembaran Negara RI Tahun 2020, No. 3. Sekretariat Negara. Jakarta.

Pemerintah Indonesia. 2014. Peraturan Menteri Kesehatan Republik Indonesia Nomor 56 Tahun 2014 Tentang Klasifikasi Dan Perizinan Rumah Sakit. Lembaran Negara RI Tahun 2014, No. 56. Sekretariat Negara. Jakarta.

Peraturan Menteri PUPR Nomor 29/PRT/2006 tentang Pedoman Persyaratan Teknis Bangunan Gedung. 
104 Perancangan Rumah Sakit Paru-Paru Kelas A Di Jakarta Timur: Konsep Arsitektur Organik

Media Elektronik (Portal Statistik Sektoral

Provinsi DKI Jakarta)

Nuraini, A., Pratiwi, H., 27 Agustus 2019.

Penyakit Tuberkulosis di DKI Jakarta Hingga

Tahun 2018,

http://statistik.jakarta.go.id/penyakit-

tuberkulosis-di-dki-jakarta-hingga-tahun-

$\underline{2018 /}$ 